\title{
Indigenizing Work as "willful work": Toward Indigenous Transgressive Leadership in Canadian Universities
}

\author{
Ahnungoonhs / Brent Debassige \\ Western University \\ bdebassi@uwo.ca \\ Candace Brunette-Debassige \\ Western University \\ cbrune2@uwo.ca
}

\begin{abstract}
As Indigenous peoples employed at a university who are working to Indigenize it from within, in this article, we share our experiences, discuss some of our challenges, and show how we draw meaning and strength from Indigenous stories to ground us in our approach. We use Indigenous, anti-oppressive, anti-racist and decolonizing theories, Indigenous standpoints, embodied experiences, and emotive responses to make explicit the lived work realities of Indigenous people in mainstream universities. Through a dialogic approach, we trace one pathway for explicating Indigenous transgressive leadership in Canadian universities. In our discussion, we situate Indigenizing work as "willful work" (Ahmed, 2014). We call for a "strategic willfulness" as a constructive orientation, for Indigenous leaders to embrace, as we continue to confront the colonial, hetero-patriarchal and whitestream nature of Canadian universities. Most importantly, we underscore the need for Indigenous leaders involved in Indigenizing work in the university to draw from Indigenous epistemological and relational ethics in their leadership work, and to be strategically willful, interruptive and transgressive.
\end{abstract}

Keywords: Indigenization, decolonizing higher education, willfulness, Indigenous transgressive leadership, $21^{\text {st }}$ century Indigenous scholar(ship)

\section{Opening}

In the time of the Seventh Fire, a New People will emerge to retrace their steps and find what was left by the trail (Benton-Benai, 1988, p. 92).

In the last 10 years, growing calls to Indigenize or decolonize universities have emerged across Canada (Gaudry \& Lorenz, 2018; Ottmann, 2013; Pete, 2015; Pidgeon, 2016; Sasakamoose \& Pete, 2015) ${ }^{\mathrm{i}}$. Beneath the chorus of Indigenous people calling for universities to change and make space for Indigenous peoples and knowledges, epistemic clashes are occurring in four predominant areas: research, methodology, theory and community (Marker, 2006). Moreover, Indigenous peoples, particularly the small number of Indigenous student leaders, staff, faculty and administrators who are expected to institutionalize this mandate - ourselves included - are situated at the nexus of these colliding worlds. In this paper, we draw on our sentient experiences

Cultural and Pedagogical Inquiry, Fall 2018, 10(2), pp. 119-138

ISSN 1916-3460 @ 2018 University of Alberta

http://ejournals.library.ualberta.ca/index.php/cpi/index 
originating from this collision and we explore our reality through a dialogue with each other. We begin by introducing ourselves.

Candace - Wachay. Waban Keezis nintishnikaas. Mushkego iskew endow. Petabeck nontonchi. My name is Candace Brunette-Debassige. I am originally from Fort Albany First Nation (Treaty 9 Territory), but I grew up in small town northern Ontario. I am a working mother, an Indigenous Affairs administrator and a $\mathrm{PhD}$ candidate, in the Faculty of Education, at Western University.

Brent - Boozhoo, Ahnungoonhs nindizhinikaaz. Adik nindoodem. M'Chigeeng nin indoonjii. Ojibwe-Anishinaabe inni endow. My given birth name and surname name is Brent Debassige. I am a proud dad of two wonderful kids and companion to my amazing partner, Candace. I am a citizen of M'Chigeeng First Nation and I currently reside in London, Ontario where I am employed as an Associate Professor, in the Faculty of Education, at Western University. At Western, I serve as the Director of Indigenous Education and as the Program Coordinator of the Master of Professional Education program, with a focus on Aboriginal Educational Leadership.

\section{A Conversational Approach}

We approach this paper as a conversation that draws on relevant theories and personal and cultural stories to share our lived experiences as Indigenous peoples labouring inside the modern university. By drawing on our individual standpoints, we endeavour to make sense of the realities of Indigenous peoples who are employed in these inherently colonial environments. Moreover, we position Indigenous story as a theoretical lens based within Indigenous epistemologies (Simpson, 2013b). Before we go any further, we would like to proactively address criticism or rejection of Indigenous standpoint based on the charge of (epistemic) relativism. The dismissal of Indigenous standpoint is often grounded in an understanding that parallels the definition of the concept of relativism provided in the Blackwell Dictionary of Modern Social Thought that states, "if true belief is defined as belief which matches an independent reality, relativism denies that beliefs can be, or can be known to be, true in this sense" (Outhwaite, 2006, p. 565). Moreover, the entry concludes with the following:

On the one hand, if there is anything universal under the sun, it is not obvious. On the other, variety is in itself never proof that all viewpoints are equally valid, and, if they were, a global relativism would be no more valid than its denial. Disputes remain fraught, since a distinction between the cognitive and the social, with the aim of explaining one in terms of the other, is easy neither to draw nor defend. (Outhwaite, 2006, p. 566)

While we acknowledge this challenge, we respectfully contend that Indigenous standpoints like ours are urgently needed at this time. Indigenous voices are most relevant in reflexively analyzing the lived embodied realities of Indigenous peoples laboring inside universities. Moreover, while not accommodating the full breadth and depth of Indigenous standpoint, we offer the following provisional distinction on the definition of relativism as is provided in an entry of the Cambridge Dictionary of Sociology:

The strongest and crudest form of the relativist attitude to knowledge is that any claim to knowledge is as good as any other. This kind of relativist does not believe that some knowledge claims are more adequate than others. He/she does not recognize the qualitative difference between an unsubstantiated opinion, for example, and a belief that 
has been subjected to current critical and self-corrective methods and rational standards of inquiry. (Turner, 2006, p. 504)

We argue that our Indigenous standpoints render criticism based on relativism to be at best, lacking adequate substantiation considering that Indigenous voices are highly marginalized in educational leadership and policy discourses. At worst, such critiques serve to perpetuate further disenfranchisement of Indigenous peoples by devaluing and further silencing Indigenous voices. In turn, relativist and other uninformed critics further condone and conceal the reproduction of settler colonial, racist, and hetero-patriarchal discursive systems of power-which we make explicit and interrupt in this paper. Moreover, we present this paper largely, as a representing research project. According to Smith (2012), "the representing project spans both the notion of representation as a political concept and representation as a form of [Indigenous] voice and expression. In the political sense colonialism specifically excluded Indigenous peoples from any form of decision making" (p. 151).

In exploring our felt experiences, we enter into a dialogue with each other conversing about issues related to the following: (a) our complex and intersectional understanding of being Indigenous (e.g., Mushkego iskew and Ojibwe-Anishinaabe inni ${ }^{\mathrm{ii}}$, respectively); (b) our differing roles inside the university; and (c) our understandings of our responsibilities to serving Indigenous communities and the project of "Indigenous educational sovereignty"iii (AguileraBlack Bear \& Tippeconnic, 2015). Collectively, these three overlapping areas inform our initial conceptualizing of an Indigenous transgressive ${ }^{\text {iv }}$ leadership approach in education.

Our lived experiences are shaped by being Indigenous and by being marked as Other within the university. Borrowing on the work of Edward Said, Linda Tuhiwai Smith (2012) describes how Indigenous peoples were constituted through a colonial discourse constructed by the West of Indigenous/Other: "knowledge about Indigenous peoples was collected, classified and then represented in various ways back to the West, and then, through the eyes of the West, back to those who have been colonized" (p. 1). As Other within the university, we are invited inside the institution but implicitly expected to accept dominant norms and when we do not, we are often pushed to the periphery, discredited and dismissed (Ahmed, 2000). For our discussion, Sara Ahmed's (2000) concept of the "stranger" is useful. As Indigenous peoples we are marked as strangers - malevolent characters and figures discursively used by dominant powers (Ahmed, 2000). Through this troubling positioning, we argue that Indigenous peoples' mere presence inside universities transgresses the boundaries of colonial whiteness in which all public institutions are firmly entrenched. We also assert that this positioning reinforces our ambivalent relationship to the university - one that is, mired in historical, ostensible missionizing and civilizing efforts, exclusion and even negligence. In this way, Indigenous peoples are often left feeling personally conflicted and at times implicated (even complicit) in a system that has historically, and at present, continues to deny Indigenous peoples' agency in educational governance and authorship in knowledge creation and dissemination processes.

In this paper, we draw on another key concept of Ahmed's (2014), “willfulness," as a useful orientation (i.e., strategic, not malicious) for Indigenous people to take up their leadership roles in relation to white colonial norms. We expand on the concept later in this paper. We recognize how colonialism and whiteness are normalized in universities - often operating in invisible, taken-for-granted ways - through structures, policies, ideologies, relationships, 
discursive practices, biases and assumptions (Henry et al., 2017). From our experiences, we know and have felt how Indigenous ways of being and doing are often positioned as a problem perceived to be a threat to the status quo, where we are assumed to be unable to manage our own affairs, unintelligent, in need of saving, needing charity and unable to speak for ourselves, unnecessarily consuming peoples time and energy, immutable, and occupying work spaces. Moreover, Indigenous people encounter these "white possessive" (Moreton-Robinson, 2015) paternalistic and colonial logics in their daily encounters with people inside universities in real and embodied ways.

\section{Context}

In today's Canadian society, universities are institutions that grant degrees; those who earn these degrees often acquire social and cultural capital of the dominant culture. Universities are often considered beacons of liberal democracy and individual freedom in the pursuit of knowledge and progress (Henry et al., 2017). Yet the modern university and its many disciplines, models of governance, organizational structures, and dominant ideologies are deeply rooted in European imperial-colonialism and the perpetuation of Western liberal ideologies including tenets of meritocracy, individualism and competition (Kuokkanen, 2007). The university is therefore deeply implicated in the continuation of deep epistemic and ontological assumptions about knowledge production and education based on Eurocentric imperatives and goals including notions of rationality, objectivity, and empiricism (Battiste, 2016).

While the modern university's roots stem back to European medieval times, the blueprint model for Canadian institutions has strong religious affiliations that involved pre-confederate importation from the imperial centre (Britain) to the settler colony (Upper/Lower Canada and later Canada). Early university structures were built on Indigenous lands and have contributed to the displacement and erasure of Indigenous peoples' presence and knowledges inside these environments and in society in general. These physical architectural and intellectual centers, although supplanted Indigenous peoples' collective rights to land, they also barricaded themselves from Indigenous peoples' entrance and participation under the guise that Indigenous peoples and their knowledges were inferior, illiterate and uncivilized. Yet ironically, Indigenous peoples have been one of the most researched groups in the academy, often written about by European scholars from expert Western colonial points of view (Smith, 1999; 2012).

After Confederation in 1867, many new universities were built and funded through endowments and government funding that included mandates that focused attention on educating settler society into elite social classes (Jones, 2014). When universities finally opened their doors to Indigenous peoples in the 1920s, churches and the settler-state (under the Indian Act legislation) attached strings: university educated Indigenous peoples were forcefully and involuntarily enfranchised which meant they lost their Indigenous treaty rights (Stonechild, 2006). By the 1970s, federal and provincial policies would begin to emerge and focus on addressing Indigenous inaccessibility through focused funding and recruitment and retention strategies; however, beneath the rhetoric of inclusion policy statements of the time were deep multicultural ideological assumptions that expected Indigenous peoples to assimilate or acculturate within the dominant university system (Kirkness \& Barnhart, 1991). Early Indigenous post-secondary education policies did not recognize Indigenous peoples' distinct rights, and continued to privilege Euro-Western theories, methodologies and ideologies in education. Overall, the higher educational system in Canada is deeply predicated upon 
Eurocentric settler-colonial assumptions, which makes the Indigenizing and decolonization project in universities today increasingly challenging (Battiste, Bell \& Finlay, 2002).

Given this context, it is often impossible for Indigenous peoples studying and working inside modern universities to forget the colonial past as its structure is an ongoing reality that shapes everyday encounters and experiences including ongoing harmful and violent experiences among students (Clark, Spanierman, Isaac, Poolkasingham, 2014; Cote-Meek, 2014) and faculty members (Bunda et al., 2012; Henry et al., 2017). Despite this troubling reality, many Indigenous peoples continue to enter the academy to accumulate social and cultural capital and use it as a political tool to advance Indigenous projects within and outside the institution. For us, we choose to be employed and labour inside the institution, helping Indigenous students to navigate its difficult terrain, create new spaces through structures, policies and services, advancing academic programs and growing disciplines, contributing to research and scholarship that is grounded in Indigenous thought, and acting as bridges between the university and Indigenous communities. We assert that, we, and other Indigenous peoples who choose to do this, mostly, undocumented and additional voluntary work, "lend" ourselves to universities, but do so at a cost, as we are often put into precarious and tenuous positions. These include times of being at odds with the institution and forced to "bite the hand that feeds us" (Tuck, 2018) by pushing back against dominant institutional norms. Indigenous leaders learn quickly that to survive and achieve Indigenous goals, we must be "willful," (Ahmed, 2014) - as we resist and combat the inherent normalized colonial whiteness embedded within the university.

\section{Indigenous Willfulness}

Sarah Ahmed (2014) writes extensively about "the will" in her book Willful Subjects, where she links the concept back to the modern era and religious moral educational understandings. Ahmed excavates the "willful child" as a common character used to portray a disobedient and unruly child in need of parental moral reform. The paternalistic characterization of the "willful child" is depicted against the backdrop of teaching children values in the context of Christian hetero-patriarchal norms. In this sense, "the will" has been historically used to define a problem and has acted as a pedagogic tool to characterize someone as not conforming to the dominant European hetero-patriarchal system. Ahmed applies her theory of "willfulness" to diversity work in higher educational settings in the United Kingdom, arguing that diversity workers act as willful workers against the normalized whiteness of institutions. It is here that we draw on Ahmed's willfulness theory and apply it to the context of Indigenous peoples working inside Canadian universities. Like Ahmed, we recognize willfulness as a necessary deviation from a larger general white [colonial] willing project of universities. For Indigenous peoples, therefore, being unwilling to become willing subjects in ongoing processes of colonialization in universities is one-way Indigenous peoples can practise willfulness. Willfulness is a reaction in relationship to and against unquestioned biases inherent within white colonial systems of power, which do not serve the goals of Indigenous educational sovereignty. It is moreover enmeshed within a sense of responsibility to a different project - an Indigenous political project based within Indigenous notions of sovereignty and futurity. As Indigenous leaders working inside universities, our sense of willfulness is situated within an Indigenous epistemological and ontological centre where we also draw meaning from Anishinaabe and Cree stories (excerpts from Anishinaabe Waynaboozhoo stories are used in this paper) for our philosophy of the will. In this paper, Waynaboozhoo is represented through the use of quotes from published literature. The quotes are inserted throughout our script as we felt it serves as a reminder to us and readers 
about Indigenous intellectual and spiritual traditions of knowing. As with Waynaboozhoo, s/he shows up in many unexpected places and, probably, all places at the same time everywhere. We assert that along with Indigenous ethics of relationality (Kovach, 2009), a willingness to be strategically willful is a necessary requirement of an Indigenous transgressive leadership approach in education. Our usage of the term "strategic" is borrowed from Graham Hingangaroa Smith's and Maggie Kovach's conversation around the need to know our limits and accept strategic concessions (Kovach, 2009, p. 90) or risk burning out.

\section{Indigenous Willful Work}

Since the release of Canada's Truth and Reconciliation Commission Report ${ }^{\mathrm{v}}$ and the associated Calls to Action (TRC, 2015), the need to redress the colonial past and present in postsecondary institutions is top of mind. At the forefront of this movement are the few Indigenous peoples, students, faculty, staff and community partners (e.g., Indigenous education council members) many of whom were involved in Indigenous projects in universities long before the TRC's Calls to Action were released with such national unified vigor. These often embattled and fatigued groups of Indigenous peoples inside universities across the country are simply continuing their work and holding universities accountable by expecting institutions to take responsibility and respond to policy directives. While many of us work in under-resourced situations, we are using our agency and the TRC policy to incite (and hopefully) mobilize further change in universities - change that is often framed as Indigenization or decolonizing work.

In the academic literature, "Indigenization" is becoming a more contested term and practice (Gaudry \& Lorenz, 2018). In our paper, we associate Indigenization with decolonizing approaches (Battiste, 2013) that aim to reform universities and equalize power relations to achieve Indigenous self-determination (Mihesuah \& Wilson, 2004) or "educational sovereignty" (Aguilera-Black Bear \& Tippeconnic, 2015). Indigenization discourses assume that the modern university needs to change, and Indigenous peoples and their knowledges can contribute to this transformation. This discourse tends to recognize the Euro-Western foundation and nature of higher educational systems and advocate for system-wide reform including curriculum, pedagogy, policy and governance changes that privilege Indigenous voices and agency (Minthorn \& Chavez, 2015; Pidgeon, 2016). In the scholarship, there are also calls for Indigenous community engagement (Axworthy et al., 2016) and the centering of Indigenous theoretical and methodological approaches (Battiste, 2017) in Indigenizing practices.

These calls to change are challenging ideologically and practically, as universities are deeply implicated in colonial and white hegemonic and administrative norms that habituate people's behaviours to work uncritically under neo-liberal and neo-colonial pressures. Moreover, Indigenous peoples are few inside the university, which means that without ongoing vigilance, the Indigenizing (decolonizing) project is at risk of being co-opted by non-Indigenous peoples who, largely, lack the knowledge and capacity needed for effective change and long-term sustainability.

While we would like to suggest that the proliferation of Indigenizing discourses points to some examples of Indigenous peoples' willfulness toward the Eurocentric nature of universities, there is also a growing chorus of scholars critiquing institutional Indigenizing practices (Gaudry $\&$ Lorenz, 2018). For example, there are debates on the degrees to which universities can change (Tuck, 2018), are actually decolonizing (Andreotti et al., 2015), and criticism of the tendency to 
make metaphors of decolonization in educational contexts, which involves practices that negate power relations, materiality and repatriation of occupied Indigenous lands (Tuck \& Yang, 2012). Critics of decolonization in practice point to an incommensurability and ask practitioners to centre on Indigenous sovereignty of lands and Indigenous futurity (Tuck \& Yang, 2012). From these critical perspectives, advocates warn against simply recognizing Indigenous peoples and shying away from the "messy, dynamic, and contradictory processes" (Sium, Desai \& Ritskes, 2012) of decolonizing universities.

\section{Our Dialogue}

"Wa-bun-noong. I saw Ni-gig (otter) swim to the east and swim back to the centre."(Benton-Banai, 1988, p. 64). Ni-gig was doing healing work for those Nishinaabe. Ohwah! (Simpson, 2013a).

Candace - Indigenous leaders inside universities are challenged by the dominance of white colonial norms and its tendency to take over, but we are also expected to navigate multiple worlds, code-switch and move in and out of epistemic realities to gain credibility and agency within the institution and within Indigenous communities. I have often found myself situated discombobulated, at times, and in tenuous positions in-between the organizations that I have worked for, and Indigenous communities that I have served. I can still vividly remember an instance where I was new to a position working in an educational organization. It was my first meeting with various partners, and I had arrived at the room early to introduce myself to some of the Indigenous community members. One of the local Elders to whom I was introduced looked at me, chuckled and asked, "Whose side are you on?" As the meeting went along, it became clear that the community needed to assert some needs and that the organization I represented at the time did not appreciate what they were trying to say. I had to help communicate what was being lost in translation. These situations are common at the cultural interface in dominant educational settings, and they thrust Indigenous leaders into the middle to act as a bridge and a translator inbetween Indigenous peoples and Euro-Western educational systems. In this space in-between, I have struggled to figure out my place and find my own voice - to learn to communicate across cultures and have the courage and skills to assert the needs of Indigenous peoples, to effectively articulate these needs in ways that institutions will hear and more importantly, respond. I have also had to grow some pretty thick skin. Building respectful and ethical working relationships has been crucial in my being able to say certain things, be heard, dispel assumptions and address issues.

Brent - I can relate to that feeling of being pulled in many conflicting directions. Indigenous faculty members are often thrust into administrative roles with little or no support, and often as pre-tenured faculty members. The threat to our well-being is real and omnipresent. Moreover, Indigenous approaches to scholarship can look quite different from the dominant expectations in terms of its priorities and goals. It's time for the university to recognize, affirm and reward $21^{\text {st }}$ century Indigenous scholar(ship) ${ }^{\mathrm{vi}}$. Active participation in "community engagement" (Canadian Institutes of Health Research, Natural Sciences and Engineering Research Council of Canada, and Social Sciences and Humanities Research Council of Canada, 2014, p. 12) is now recognized by the Government of Canada's Panel on Research Ethics in the Tri-Council Policy Statement as a research-related activity that is common within Indigenous research, but is not well understood and rarely supported within the academy. For example, $21^{\text {st }}$ century Indigenous scholarship involves activities that connect Indigenous scholars to Indigenous communities in 
ongoing ways where the co-production of knowledge is mobilized over time and in situ. $21^{\text {st }}$ century Indigenous scholarship includes lifelong learning of the cultural, linguistic and participatory epistemic and ontological frames found within Indigenous sites of learning such as ceremonies. I am calling for post-secondary institutions to create (or revise existing) policies to recognize and support Indigenous scholars' wide range of labour. Institutions need to recognize and support scholars' involvement in ongoing learning activities that contain the constitutive elements of our intellectual traditions (e.g., ceremonies, land-based education and Indigenous language-acquisition activities such as language camps). Moreover, $21^{\text {st }}$ century Indigenous scholarship must fit under the Faculty workload definitions of Research and Teaching and involve redefining impact factor. For example, rather than measuring the number of citation counts in an academic journal for a peer-reviewed publication (with tier 1 as the pinnacle), we need to be asking, what is the "community-based impact factor" of the scholarship? We need discussion between $21^{\text {st }}$ century Indigenous scholars and Indigenous community members on ideas and approaches that support (informal) peer-review in situ. Once established, informal peer-reviewed contributions must be considered of close approximate value to formal peerreviewed documents in departmental/faculty workload considerations and in Tenure and Promotion evaluation processes. This type of scholarship should not fall under the category of "community service," as this greatly minimizes and is dismissive of its $21^{\text {st }}$ century academic contribution.

"Zha-wa-noong. I saw Ni-gig (otter). I saw otter swim to the South and swim back to the centre." (Benton-Banai, 1988, p. 64). Ni-gig (otter) was doing healing work for those Nishinaabe. Ohwah! (Simpson, 2013a).

Candace - Once I became a university administrator, I began to encounter very different challenges. Managing different expectations including the emotional labour of maintaining relationships with Indigenous peoples while simultaneously upholding (and at times resisting) the policy, fiscal, and human resource management is the most difficult. I have observed some Indigenous people dismiss the work of Indigenous administrators working inside universities. They use colonial authenticity discourses to imply that administrative work or the people themselves are "not Indigenous enough" or that they are "assimilated" and/or "foolishly wasting their time" trying to convince power brokers of Indigenous value when they should be working on changing ourselves and building our own educational system. For me, it's not that simple. It never is.

I have also often been uncomfortable when I am labelled an "Indigenous leader" by nonIndigenous people inside the university because I am aware that many Indigenous peoples do not necessarily define leadership in a Euro-Western way that privileges a title or position within an organization. In the emerging academic literature on Indigenous leadership, Western/Indigenous epistemic distinctions of leadership are taken up. For example, Gregory Cajete (2017) acknowledges that dominant leadership paradigms tend to be individualistic and are less congruent with Indigenous communal and culturally relevant approaches to leadership. Warner and Grint (2006) also distinguish between Western and Indigenous models of leadership; they note that Western leadership tends to privilege hierarchal organizational power structures and its bureaucracies, whereas Indigenous community models of leadership are based in heterarchical, situational and community needs. I believe these differing conceptions of leadership surface and 
create conflicts within some Indigenous people who occupy formal leadership roles and navigate the in-between spaces of Indigenous and non-Indigenous epistemologies.

Brent - That is interesting. I do not tend to look at myself as a leader; I see myself more as a helper to other Indigenous peoples. But working in the institution has hardened me, and I have had to learn to be outspoken. I have forced myself to find the confidence to interrupt and transgress the norms of the status quo due to a fear that Indigenous perspectives will be silenced if I do not speak out. In the Oxford English Dictionary, the word "transgress" has two related meanings: (a) to "go beyond the limits of (what is morally, socially or legally acceptable); [and] (b) in Geology, to spread over (the sea) an area of land" (Soanes \& Stevenson, 2003, p. 1874). In addition, I know we both concur with bell hooks (1994) when she suggests that "we have the opportunity to labor for freedom, to demand of ourselves and our comrades, an openness of mind and heart that allows us to face reality even as we collectively imagine ways to move beyond boundaries, to transgress" (p. 207). As Canadian "Status Indians," our mere presence in mainstream universities today situates us as transgressors to the hegemonic norms of higher education formed by a Western paradigm and the colonial nation-state imposed on our lands. The early legal precedent for this Indigenous transgression is entrenched in the Indian Act legislation of Canada, which from 1876 to 1927 prohibited "Status Indian" participation in higher educational institutions unless they enfranchised and relinquished their "Status Indian" rights. The intermingling of colonial and legal doctrine enmeshed within Canada's assimilatory history not only involved imposing definitions and colonial boundaries upon who is or is not considered a "Status Indian," it also involved demarcating which qualifications are appropriate to obtain a higher education. This brings up the longstanding and all-too-often unacknowledged assumption inherent to colonial ideologies, that is, the stereotypical belief that educated Indians cannot be Indians, especially as it concerns the Othering gaze of us and our knowledge systems as immutable. Today, for Indians as Indians to assert their position into universities is to transgress the norms of the dominant culture. The resulting systemic exclusion of Indians as Indians in formal education has a long and messy history along with many consequences, as the establishment and co-creation of most universities in Canada were conceived and moulded during the $19^{\text {th }}$ century. Indigenous peoples' contribution to the formation of modern universities has therefore been heavily impaired by these legal and ideological exclusions, which has not only blocked and impacted Indigenous peoples' access and full participation but has also involved barring firsthand Indigenous epistemic understandings in shaping the disciplines, goals and norms of the modern academic institution.

Candace - That makes a lot of sense to me, especially as it relates to the expectations and challenges that I have faced working in the university. As an administrator, I have often worried about losing myself as a Cree woman. The threat of co-optation is ever-present for me in these kinds of roles. Taiaiake Alfred (1999) warns Indigenous leaders working inside Euro-Western political systems who are subordinated to governmental, social, and economic frameworks to bring attention to the ongoing threat of their colonial co-optation. Alfred warns Indigenous leaders of the real threat of internalizing colonial mentalities, which he describes as "the gradual assumption of the values, goals, and perspectives that make up the status quo" (p. 70). He calls on Indigenous leaders to be self-reflexive and constantly assess the degree to which co-optation affects their thought processes; analyze the degree of control governments have over Indigenous goals and objectives; and infuse Indigenous approaches to decision making and governance (Alfred, 1999). Yet as university administrators, we are often working under such immense

Cultural and Pedagogical Inquiry, Fall 2018, 10(2), pp. 119-138

ISSN 1916-3460 @ 2018 University of Alberta

http://ejournals.library.ualberta.ca/index.php/cpi/index 
pressures including a fast-paced and under-resourced neoliberal environment that it is difficult if not impossible sometimes - to take time to reflect deeply and critically about our many choices. In this role, I have found it helpful to work collaboratively with the university's Indigenous education council, Indigenous student councils, and Elders on-campus for input and direction. They remind me when I get off track. It has also been extremely important for me to find ways to reconnect with community and stay tethered to Indigenous community realities.

Brent - And I think that is where it is important for Indigenous staff and faculty members to work closely together. While pre-tenured faculty members often feel anxiety about their job security, I have always felt it was important for me to work closely with Indigenous students, staff and faculty on campus by sitting on Indigenous committees to push the administration. Please do not misunderstand me on this point, though. I am not suggesting that Indigenous peoples be malicious towards administration. I firmly believe that we should always be harnessing our intellect and advancing thoughtful critically engaged persuasive arguments, strategies and approaches. This approach involves a highly developmental and "inquiry-minded" (Rallis \& Rossman, 2012) dialogical process where Indigenous people can begin cutting their teeth as graduate (or even undergraduate) students. Faculty life is a different world and, on some level, requires one to orient themselves to the plethora of policies and the challenging and competition-based circumstances of the university environment. Faculty members have protection under policy clauses such as academic freedom in collective agreements which permit us to be outspoken and critical of administration. I do not know of any examples where staff members have the same protection. In my opinion, this lack of protection puts Indigenous staff members in a more vulnerable position, because if they push too hard against the university administration, they risk losing their reappointment, promotion and/or advancement. I also believe that this puts Indigenous staff administrators at higher risk for being co-opted by the university. This is not to say that all Indigenous faculty members are immune to co-optation or that all Indigenous staff administrators are co-opted though. Put simply, we need to come together to keep each other grounded and be critically engaged with each other's thinking and behaviour. Moreover, if we are expecting the university to change, Indigenous faculty and staff have to collectively demand it and find ways to mobilize and lead change. However, even in that instance, insufficient or piecemeal investments into Indigenous human and financial resourcing will set us and universities on a trajectory for failure.

Inadequate resourcing remains the largest obstacle to system-wide change and universities need to strategically hire more Indigenous faculty and staff members to, at least initially, support areas of strength and the development of critical masses (plural) of Indigenous peoples. In concert with hiring, universities need to contribute to developing and offering distinct approaches for recruiting and retaining Indigenous peoples that include paid internships that respond to Indigenous peoples' realities (e.g., child care needs, poverty, familial and community responsibilities, etcetera), and establishing pipelines that advance their most talented Indigenous students. Prospective talent should be identified early so that universities can provide full-tuition relief, student research stipends, scholarships and bursaries, adequately funded employment (and on the job training) during the summer months, child care support, professional development training and other academic training. Many of these recommendations are not new but essential to success when responding to TRC policy directives. These suggestions are also only a starting point. Indigenous faculty and staff members need safe spaces for critical dialogue with each other about relevant issues. These safe and culturally responsive spaces (e.g., guided by Elders) 
for Indigenous peoples need to be created and protected in a way that allows for candid discussions about the university without fear of reprisal. If information is leaked or people are excluded, the trust can be broken and will create a fragmented group. Culturally-based protocols could be developed and useful for governing processes through each person in the space.

\section{"Niing-ga-be-uh-noong. I saw Ni-gig (otter). I saw otter swim to the West and swim back to the centre." (Benton-Banai, 1988, p. 64). Ni-gig (otter) was doing healing work for those Nishinaabe people. Ohwah! (Simpson, 2013a).}

Candace - Collaboration and communication are so important in this work. Working as an Indigenous woman in a formal Indigenous specific administrative role inside a university has been, at times, an Othering experience where I have been confronted with colonial racist and sexist attitudes and problematic positionings of me in what I refer to as "Other-Within." OtherWithin occurs when Indigenous peoples are distanced and differentiated from the dominant group - and moreover assumed to be inferior and/or in deficit from the dominant group. It is always unsettling and disappointing when you hear these kinds of sentiments (often revealed in assumptions or conversational slips) coming from colleagues inside the university. And it happens a lot more than non-Indigenous peoples realize. Suddenly someone reveals their colonial biases in a telling and troubling comment filled with negative assumptions and generalizations about your Indigeneity or Indigeneity in general. You feel like you have been hit in the gut, and you didn't see it coming. Others in the room notice, but they do not say anything. Maybe they are in shock? Some of them even change the subject quickly to avoid an uncomfortable conversation. You are beside yourself. It is hard to move forward in the conversation in the relationship without an acknowledgement of the problematic assumptions and statements. It is harmful, and a can trigger colonial trauma. The remnants of this encounter need to be processed and talked about in order for you to move on. The relationship with that person is mired otherwise. The trust is broken. Yet it could have been salvaged if we had only acknowledged it and had a mutual understanding and framework to talk about it.

Brent - I think of the remnants of those types of encounters as something that Indigenous peoples carry within them. Some people, me included, are triggered by these occurrences because they remind them of felt oppression. I refer to this response as an Indigenous emotive response (IER). Specifically, IER reveals itself through an embodied feeling in response to a microaggression (Clark, Kleiman, Spanierman, Isaac, \& Poolokasingham, 2014; Sue, Bucceri, Lin, Nadal, \& Torino, 2007), authoritarianism, co-optation, lateral violence, and colonialracialized-gendered-able bodied Othering of Indigenous peoples and our knowledge systems. The felt experience can manifest into insult, shock, anger or internalized shame. As an Indigenous faculty member, I frequently experience and notice IERs, so I developed my own heuristic technique to respond when I am able. As I see it, IER is the culmination of Indigenous practical or situated knowledge that is acquired through daily lived realities within a colonial settler state. Moreover, an IER is the constitutive elemental property of an Indigenous counter discourse. In order for the emotive response to become dialogically coherent, there must be an intentional effort exerted in unpacking and contextualizing the emotive response in situ. This intentional effort is needed to interrupt the uncritical habituation of university actors who seek to restore calm and institute the procedural order of meetings or gatherings, in effect, glossing over a troubling interaction and missing an opportunity to examine and learn from it. The consequence for undermining or dismissing an IER is the restoration of the status quo, the 
subjugation of Indigenous lived experiences, the loss of a cross-cultural learning, and damage to Indigenous - non-Indigenous and Indigenous - Indigenous relationships (in some cases, irreparable damage).

I differentiate IER from people who are malicious or unnecessarily resistant, combative or egotistical, which is difficult to evaluate in practice without knowing the localized and personal interrelationships between people who are present. Albeit seemly obvious, one needs to understand that not all Indigenous peoples are the same and one needs to have, in sociological terms, the Indigenous social capital to increase the effectiveness of differentiating between the complex nuances on a case-by-case basis. If one were to take the IER as an opportunity to explicate oppression, rather than dismissively scuttling it, then oppression can be unveiled to those in attendance as a normative structure and not an event (Wolfe, 2006). A shared understanding of oppression and its consequences creates potential for meaningful outcomes. To be effective in this task; however, is not easy. For the Indigenous scholar, high rates of IERs to microaggressions and other related forms of oppression in institutions are substantial. While not a blueprint, one can do several things in these instances including: a) be strategic in determining whether the response is worth explicating; b) evaluate whether the response is understandable and can be sufficiently contextualized; c) differentiate whether it is IER or one who is being malicious, deliberately combative or egotistical; d) determine the possibility of discursively scaffolding and unpacking the response as it relates to anti-oppressive, decolonizing, and anticolonial theories; and d) assess whether this is an opportune time to be wilful (or allow for an organic unfolding of discontent and varied forms of protest). Similar in complexity to the culmination of applying the unique blend of the requisite academic abilities, skillsets, aptitudes and "practical wisdom" (Schwandt, 2012, p. viii) needed in mainstream inquiry and scholarship, I believe there are parallel elements of social capital that is the distinct disposition of some Indigenous scholars. Once the informed Indigenous scholar intuitively understands, recognizes and chooses to respond to the emotive response in situ, the cognitive processing and discursive reasoning contains consequences for the Indigenous scholar. The exertion of the cognitive labour is demanding and exhausting and beyond the normative expectations of most other faculty members. This additional 'reconciliatory' labour is undocumented and never counted as official workload contribution, which leaves this activity firmly in the domain of a moral and ethical imperative where Indigenous scholars are left to shoulder the burden.

Candace - That explanation nicely captures the need for more Indigenous faculty members and outlines the distinctive contribution that they can and do make to university environments. As you know, I left a staff university administrative position for a time to pursue my doctoral degree. This time away allowed me to reflect on my experiences in administration. The scholarly disposition was less emotionally charged than when I was immersed in my staff role of a university administrator, which I often equate with being "under the knife." As a result of my time away, I have a deeper understanding of the internal epistemological conflicts I endured, and I have developed ways to reflect on my role and tensions in more critical ways. I also have a much deeper respect for the difficult position of Indigenous university administrators. Administrators are certainly in a unique position where they have to wear many hats and straddle many different and sometimes conflicting positions without losing themselves.

Like you have alluded to, I have spent much time convincing people in powerful positions that Indigenous initiatives matter. Convincing is about changing someone`s mind, and 
it is an innately inferior position. Developing relationships with internal power brokers has been crucial and has helped to avoid wasting time and energy on people who do not have the authority, influence or desire to change the system. In this way, we cannot talk about relationships without talking about power differences and hierarchal divisions of labour. While relationships matter and are important, we cannot talk about relationships simply - otherwise we are ignoring the unequal power relationships that operate in dominant institutions between people. Senior administrative support makes a huge difference in getting the work done. I have learned that it also makes a significant difference where Indigenous Affairs is situated in the university organizational structure. This is a good example of how systemic power and relationships impact Indigenous work.

Brent - But, of course, not all senior administrators always listen - and that requires heavy intellectual and emotional labour too. When working with people in positions of power (who are predominantly non-Indigenous), I have used different strategies (together and separately) to make the case more compelling. I have used rights-based rationales to Indigenous education, leveraged policy mandate arguments, talked about systemic barriers as justifications, even made the business case. I have named colonialism, racism, a structural ideology of whiteness, and systemic Eurocentrism. I have used a myriad of strategies to try and change the way administrators think so that they will act differently and support our work. There is no doubt that inside the university we are placed within inferior positions of power. Our voices are few and marginalized. Inequity is an understatement.

Candace - Yes, I agree. I have experienced the need to prove myself (beyond non-Indigenous people, I believe) to develop credibility and earn trust from gatekeepers. There is a deep unacknowledged distrust of Indigenous peoples among some non-Indigenous gatekeepers inside the university. I think this distrust is part of the colonial mind that operates subconsciously where Indigenous peoples are assumed to be dysfunctional and unable to manage their affairs. Unfortunately, as administrators we often have to overcome this inherent colonial assumption. So, I do not expect trust automatically anymore. I assume that I will have to work twice as hard to get it and I am prepared to do that. I do not think it's right, but I do what I must to move the agenda forward. What is challenging systemically is that Indigenous people are not always in positions of power (e.g., do not report to people in positions of authority or to people with aptitude and skill set to advocate for us) inside the institution. I have also noticed that some people are afraid to take risks to rock the boat too much, and this fear of reprisal in my experience has stifled Indigenous growth and innovation. Our inferior position in the university structure also calls that every time a new senior administrator is hired, which is generally every four years, the education, relationship-building and proving oneself process, starts all over again.

Brent - On the surface, Indigenous peoples may seem to be celebrated and/or tolerated in Canadian universities, but at a deeper level amidst the university's rhizomatous nature, its structures and norms continue to give breadth and depth to Western ways of knowing, being and doing - wherein Indigenous peoples are constantly reminded of a bygone era where we remain Indian-Act Indians and ipso facto, do not belong. At the end of the day, to enact change, policies and practices must be radically revised to be more responsive to Indigenous realities, and there must be an interruption in the hegemonic practices and uncritical ideologies that make up the institutional memory. Until this paradigmatic shift occurs in universities, the few Indigenous peoples who lead the work will remain transgressors. 
"Gi-way-din-noong. I saw Ni-gig (otter). I saw otter swim to the North and swim back to the centre." (Benton-Banai, 1988, p. 64). Ni-gig (otter) was doing healing work for those Nishinaabe people. Ohwah! (Simpson, 2013a).

Candace - The enormity of change that is required to Indigenize and decolonize the modern university system is complex, layered - and honestly, a little overwhelming and unrealistic to expect overnight. This change that we so desire and deserve will not take place without us and needs to happen beyond policy levels - it is a radical shift in consciousness and practice. It demands a critical look at how power operates and reproduces itself in dominant institutions in ways that exploit, silence and oppress Indigenous peoples and knowledges. It calls on epistemological and conceptual shifts in our understandings of leadership, policy, practice, community, theory, methodology and research. It also calls for a re-education and unlearning of the colonial mindset and its underlying logics. As communicated in a widely shared axiom in Indigenous academic circles, and as should be obvious, universities cannot Indigenize the academy without Indigenous peoples. In other words, to see impactful change, universities must be willing to hire and train more Indigenous peoples in all types of positions. They must be willing to invest in Indigenous curriculum and programming. Without substantive focus on hiring more Indigenous peoples, we risk overworking those few Indigenous peoples (who by default) take up the Indigenizing work.

Brent - Agreed! Without universities hiring more Indigenous peoples, the predominantly nonIndigenous staff and faculty will be left to take up Indigenizing efforts within the existing infrastructure. To be clear, using existing resourcing and infrastructure is not a response to the TRC's Calls to Action. While activities may be completed with good intentions, this will have unintended consequences and involves a lot of risk, including a further disempowerment of Indigenous peoples' voices and disenfranchisement of Indigenous communities. Let us not forget the increased workload on the already overworked and overwhelmed Indigenous faculty and staff members when the frequency of crises is unbearable. The risk to universities is the loss of their existing complement of skilled Indigenous labour because people are fed up with the labour conditions and neglect. In contemporary parlance, that is an epic fail! A troubling response to these concerns is to do nothing until a sufficient number of Indigenous employees arrive, while simultaneously ignoring and avoiding responsibility for the neglect that has transpired and is the root cause of the problem. To, once again, be clear: waiting for more Indigenous staff and faculty members to be hired is not a response either. There is urgency for immediate investments and creative solutions. For example, senior university administrators could mandate every department and unit to spend a set percentage of their overall operating budget on Indigenous faculty and staff employment hiring along with a complementary programming budget for Indigenous specific initiatives, or they lose the dollars to a department or unit that will make the investments. While there is no arbitrary figure that is an automatic fit for all, an annual fiscal contribution that is substantive would transform institutions quickly, but if history tells us anything there will be a lot of excuses for why this will not work or cannot be done. Substantive investments are needed now, and anything less is answering a call to inaction. Of course, hiring Indigenous peoples is not a panacea either, but it is certainly a necessary starting point. 


\section{Closing}

As prophesied in the Seven Fires Teachings of the Anishinaabe, "Two nations will join to make a mighty nation," and the Sacred Fire will be lit again (Benton-Benai, 1988, p. 93). More recently, there is a resounding echo of Indigenous voices shifting the way we think about education, and in turn, advancing universities responsibilities to foster renewed education and relationships between Indigenous and settler societies. Indigenous peoples' growing presence in universities is undoubtedly contributing to deep ontological and epistemological shifts in the ways we are thinking about theory, research, policy, leadership and ethics. In this paper, we have pointed to early conceptualizing around an Indigenous transgressive leadership approach which draws on the need to be strategically willful in Indigenizing universities. Moreover, this paper reminds us to stay connected to our stories and teachings in this process. While we have framed Indigenizing work as willful work because it resists and transgresses the dominant colonial white norms of the modern university, we are also reminded as Indigenous peoples' (Anishinaabe/Cree here respectfully) to pay attention to $\mathrm{Ni}$-gig (otter) and return to Indigenous sites of learning to understand his/her powerful messages too.

\section{Dedication:}

We dedicate this paper to yesterday's, today's and tomorrow's Indigenous leaders in all their many forms.

\section{Acknowledgements:}

We would like to acknowledge Huia Tomlins-Jahnke, Sandra Styres, Spencer Lilley, and Dawn Zinga who are the editors of the forthcoming book, Indigenous Education: New Directions in Theory and Practice. They hosted a workshop that preceded the World Indigenous Peoples Conference on Education held in Hawaii, U.S.A. in May 2014. Our participation in the session was helpful in the early development of this paper; especially the feedback provided by attendee Linda T. Smith and her suggestion that we explore the word transgress as a useful term for locating our discussion.

We acknowledge our Indigenous and non-Indigenous colleagues in our home institution at Western University where we have cried, laughed, struggled, resisted, collaborated, and debated with each other. We continue to learn much along our journeys.

Finally, we would like to acknowledge where our writing occurred which was on the Indigenous traditional territory of the Attawandaran (Neutral), Anishnabe and Haudenausaunee people where today three vibrant First Nations now live: the Chippewas of the Thames First Nation, the Munsee Delaware Nation and the Oneida Nation of the Thames. The Dish with one Spoon is a significant Wampum to this territory along with the London Township and Sombra Treaty of 1796. 


\section{Endnotes:}

${ }^{\mathrm{i}}$ In addition to the scholarship, several national organizations in higher education in Canada have released public Indigenous policy statements as follows: Universities Canada's Principles on Indigenous Education (June 2015); the Canadian Association of University Teachers (CAUT)'s Policy Statement on Indigenizing the Academy (November 2016); the Council of Ministers of Education, Canada (CMEC) Learn Canada 2020 report (2008); and Association of Canadian Deans of Education's Accord on Indigenous Education (2007).

${ }^{i i}$ For an in-depth explanation of an Ojibwe-Anishinaabe inni perspective as it relates to Indigenous research see Debassige $(2010 ; 2013)$.

iii Indigenous educational sovereignty "involves decolonizing the systems of a solely Western worldview education and specifically developing culturally responsive education systems to replace assimilationist models of education. It is considered imperative to the cultural sovereignty and survival of Indigenous communities" (Aguilera-Black Bear \& Tipperconnic, 2015, p. 5).

${ }^{\text {iv }}$ We owe a debt of gratitude to Linda Tuhiwai Smith for suggesting that we use of the concept, "transgress" as part of our work. Her insightful commentary was imparted to us at a pre-gathering as part of the World Indigenous Peoples Conference in Education (WIPCE) held in Hawaii in 2014.

${ }^{v}$ Canada's Truth and Reconciliation Commission (TRC) was launched in 2008 as part of the Indian Residential Schools Settlement Agreement (IRSSA) as a process to document the experiences and impacts of residential school on Indigenous children and their families. In December 2014, the Commission released 94 calls to action to redress this painful history and move toward reconciliation in Canada. In the document, universities were identified, as playing leadership roles in addressing reconciliation in education.

${ }^{v i}$ The concept, $21^{\text {st }}$ century Indigenous scholar(ship), is a new conceptualization of mine that builds on Graham Hingangaroa Smith's notion of "Indigenous theorizing" (Smith, 2005, p. 10), and signals the significance of Linda Tuhiwai Smith's seminal book, Decolonizing Methodologies: Research and Indigenous Peoples (Smith, 1999), to Indigenous scholarship, globally. In my own work, I have been involved in Indigenous theorizing as praxis scholarship since the early 2000's. In 2003, my thinking coalesced with a type of interruptive-activist-work in my home community of M'Chigeeng First Nation alongside my first involvement in Anishinaabe ceremonies. While partnering with First Nations communities in southwestern Ontario in offering graduate programming in the communities along with my recent involvement with a First Nations With Schools Collective, I have continued to learn and develop my understanding of what it means to be a $21^{\text {st }}$ century Indigenous scholar who conducts $21^{\text {st }}$ century Indigenous scholarship as a research-related activity. I intend to elaborate on these ideas in future publications. 


\section{References}

Aguilera-Black Bear, D., \& Tippeconnic III, J. W. (2015). Voices of resistance and renewal: Indigenous leadership in education. Norman, OK: University of Oklahoma Press.

Ahmed, S. (2014). Willful subjects. Durham \& London, UK: Duke University Press.

Ahmed, S. (2012). On being included: Racism and diversity in institutional life. Durham \& London, UK: Duke University Press.

Ahmed, S. (2000). Strange encounters: Embodied others in post-coloniality. London \& New York, NK: Routledge Taylor \& Francis Group.

Alfred, T. (1999). Peace power and righteousness: An Indigenous manifesto. New York, NY: Oxford University Press.

Andreotti, V. D., Stein, S., Ahenakew, C., \& Hunt, D. (2015). Mapping interpretations of decolonization in the context of higher education. Decolonization: Indigeneity, Education \& Society, 4(1), 21-40.

Axworthy, L., De Riviere, L., \& Moore-Rattray, J. (2016). Community learning and university policy: An inner-city university goes back to school. The International Indigenous Policy Journal, 7(2), 1-13.

Battiste, M. (2017). Forward. In F. Pirbhai-Illich, S. Pete, \& F. Martin (Eds.), Culturally responsive pedagogy: Working toward decolonization, indigeneity, and interculturalism. (pp. vii-xi) Cham, Switzerland: Palgrave Macmillan.

Battiste, M. (2016). Visioning a Mi'kmaw humanities: Indigenizing the academy. Sydney, Nova Scotia: Cape Breton University Press.

Battiste, M. (2013). Decolonizing education. Nourishing the learning spirit. Saskatoon, SK: Purich Publishing Limited.

Battiste, M., Bell, L., \& Finlay, L. M. (2002). Decolonizing education in Canadian universities: An interdisciplinary, international, Indigenous project. Canadian Journal of Native Education, 26(2), 82-95.

Benton-Banai, E. (1988). The Mishomis Book: The Voice of the Ojbway. Minneapolis, MN: University of Minnesota Press.

Bunda, T., Zipin, L., \& Brennan, M. (2012). Negotiating university 'equity' from Indigenous standpoints: a shaky bridge. International Journal of Inclusive Education 16(9), 941-957.

Cajete, G. A. (2017). Indigenous education and the development of Indigenous community leaders. Leadership, 12(3), 364-376. 
Canadian Institutes of Health Research, Natural Sciences and Engineering Research Council of Canada, and Social Sciences and Humanities Research Council of Canada (2014). TriCouncil Policy Statement: Ethical Conduct for Research Involving Humans. Retrieved from: http://www.pre.ethics.gc.ca/eng/policy-politique/initiatives/tcps2-eptc2/Default/.

Clark, A. D., Kleiman, S., Spanierman, L. B., Isaac, P., \& Poolokasingham, G. (2014). "Do you live in a teepee?" Aboriginal students' experiences with racial microaggressions in Canada. Journal of Diversity in Higher Education, 7(2), 112-125.

Coulthard, G. (2008). Red skins white masks: Rejecting the colonial politics of recognition. Minneapolis, London, England: University of Minnesota Press.

Cote-Meek, S. (2014). Colonized classrooms: Racism, trauma and resistance in post-secondary education. Halifax \& Winnipeg, MB: Fernwood Publishing.

Debassige, B./Ahnungoonhs. (2013). Building on conceptual interpretations of Aboriginal literacy in Anishinaabe research: a turtle shaker model. Canadian Journal of Education, 36(2), 4-33.

Debassige, B./Ahnungoonhs. (2010). Re-conceptualizing Anishinaabe mino-bimaadiziwin (the good life) as research methodology: a spirit centered way in Anishinaabe research. Canadian Journal of Native Education, 33(1), 11-28.

Gaudry, A., \& Lorenz, D. (2018). Indigenization as inclusion, reconciliation, and decolonization: Navigating the different visions for indigenizing the Canadian Academy. AlterNative: An International Journal of Indigenous Peoples 14(3), 218-227.

Henry, F., Dua, E., James, C. E., Kobayashi, A., Li, P., Ramos, H., \& Smith, M. S. (2017). The equity myth: Racialization and Indigeneity at Canadian universities. Vancouver \& Toronto: UBC Press.

hooks, b. (1994). Teaching to transgress: Education as the practice of freedom. New York: Routledge Publishing.

Jones, G. A. (2014). An introduction to higher education in Canada. In K. M. Joshi \& Saee Paivandi (Eds.), Higher Education Across Nations (pp. 1-38). New Delhi, India: B. R. Publishing.

Kirkness, V. J., \& Barnhardt, R. (1991). First Nations and higher education: The four R's-respect, relevance, reciprocity, responsibility. Journal of American Indian Education, $30(3), 1-15$.

Kovach, M. (2009). Indigenous methodologies: Characteristics, conversations, and contexts. Toronto, ON: University of Toronto Press.

Kuokkanen, R. (2007). Reshaping the university: Responsibility, Indigenous epistemes, and the logic of the gift. Vancouver, BC \& Toronto, ON: UBC Press.

Marker, M. (2004). The four R's revisted: Some reflections on First Nations and higher education. In Finlay Finola \& Andres Lesley (Eds.), Student affairs: Experiencing higher education (pp. 171-188). Vancouver, BC: UBC Press.

Cultural and Pedagogical Inquiry, Fall 2018, 10(2), pp. 119-138

ISSN 1916-3460 @ 2018 University of Alberta

http://ejournals.library.ualberta.ca/index.php/cpi/index 
Mihesuah, D. A., \& Cavender-Wilson, A. (2004). Indigenizing the academy: Transforming scholarship and empowering communities. London, UK: University of Nebraska Press.

Minthorn, R., \& Chavez A. F. (2015). Indigenous leadership in higher education. New York, NY: Routledge.

Moreton-Robinson, A. (2015). The white possessive: Property, power and Indigenous sovereignty. Minneapolis \& London, UK: University of Minnesota Press.

Moreton-Robinson, A. (2013). Towards an Australian Indigenous women's standpoint theory: A methodological tool. Australian Feminist Studies, 28(78), 331-347.

Ottmann, J. (2013). Indigenizing the academy: Confronting "contentious ground". A hardcopy $40^{\text {th }}$ Anniversary Special Edition of The Morning Watch. Retrieved from: http://www.mun.ca/educ/faculty/mwatch/vol40/winter2013/indigenizingAcademy.pdf

Outhwaite, W. (Ed.). (2006). The Blackwell dictionary of modern social thought (2 ${ }^{\text {nd }}$ ed.). Malden, MA: Blackwell Publishing.

Pete, S. (2016). 100 Ways: Indigenizing \& decolonizing academic programs. Aboriginal Policy Studies, 6(1).

Pidgeon, M. (2016). More than a checklist: Meaningful inclusion in higher education. Cogitatio Social Inclusion, 4(1), 77-91.

Rallis, S. F., \& Rossman, G. B. (2012). The research journey: introduction to inquiry. New York, NY: The Guilford Press.

Sasakamoose, J., \& Pete, S., (2015). Toward Indigenizing university policy: Kakweiyiniwastakihci-kiskinwahamakamikohk wiyasiwacikanisa. Education Matters, 3(1).

Schwandt, T. A. (2012). Forward. In S. F. Rallis \& G. B. Rossman, The research journey: introduction to inquiry (pp. vii-ix). New York, NY: Guilford Press.

Simpson, B. L. (2013a). The gift is in the making: Anishnaabeg stories, retold by Leanne Simpson. Winnipeg, MB: Highwater Press.

Simpson, B. L. (2013b). Theorizing resurgence from within Nishnaabeg thought. In J. Doerfler, N. J., Sinclair, \& H. K., Stark (Eds.), Centring Anishinaabeg studies: Understanding the world through stories (pp. 279-293). Winnipeg, MB: University of Manitoba Press.

Sium, A., Desai, C. \& Ritskes, E. (2012). Toward the 'tangible unknown': Decolonization and the Indigenous future. Decolonization: Indigeneity, Education \& Society, 1(1), I-XII.

Smith, G. H. (2005, May). Notes on the problematic of 'Indigenous theorizing': a critical reflection. Paper presented at the University of Washington, Native Graduate seminar series in Seattle, USA.

Smith, L. T. (1999). Decolonizing methodologies: Research and Indigenous peoples. New York: Zed Books.

Cultural and Pedagogical Inquiry, Fall 2018, 10(2), pp. 119-138

ISSN 1916-3460 @ 2018 University of Alberta

http://ejournals.library.ualberta.ca/index.php/cpi/index 
Smith, L. T. (2012). Decolonizing methodologies: Research and Indigenous peoples (2nd ed.). New York: Zed Books.

Soanes, C., \& Stevenson, A. (Eds.). (2003). Oxford Dictionary of English (2 ${ }^{\text {nd }}$ edition, revised). Oxford, England: Oxford University Press.

Stonechild, B. (2006). The new buffalo: The struggle for Aboriginal post-secondary education in Canada. Winnipeg, MB: University of Manitoba Press.

Sue, D. W., Bucceri, J., Lin, A. I., Nadal, K. L., \& Torino, G. C. (2007). Racial microaggressions and the Asian American experience. Cultural Diversity and Ethnic Minority Psychology, 13(1), 72-81.

Truth and Reconciliation Commission of Canada (TRC). (2015). Honouring the Truth, Reconciling for the Future: Summary of the Final Report of the Truth and Reconciliation Commission of Canada.

Tuck, E. (2018). Biting the university that feeds us. In M. Spooner \& J. McNinch, Dissident knowledge in higher education (pp. 149-168). Regina, SK: University of Regina Press.

Tuck, E., \& Yang, K. (2012). Decolonization is not a metaphor. Decolonization: Indigeneity, Education \& Society, 1(1).

Turner, B. S. (Ed.). (2006). The Cambridge dictionary of sociology. Cambridge, UK: Cambridge University Press.

Warner, L. S., \& Grint, K. (2006). American Indian ways of leading and knowing. Leadership, 21(2), 225-244.

Western University. (n.d.). Welcome, acknowledging territory. Retrieved from: http://www.indigenous.uwo.ca/welcome/index.html

Wolfe, P. (2006). Settler colonialism and the elimination of the Native. Journal of Genocide Research, 9(4), 387-409. 